\title{
DISCUSSION
}

The Editorial Board of The Ukrainian Biochemical Journal will gladly provide a venue for opinions, reactions and judgments on this paper.

\section{TAUTOMERIC HYPOTHESIS: TO BE OR NOT TO BE? QUANTUM-MECHANICAL VERDICT}

\author{
O. O. BROVARETS, ${ }^{\bowtie}$, D. M. HOVORUN
}

Institute of Molecular Biology and Genetics, National Academy of Sciences of Ukraine, Ukraine;

凶e-mail: o.o.brovarets@imbg.org.ua

Received: 07 April 2020; Accepted: 15 May 2020

This paper represents itself comment on the work "Soler-Polo, D., Mendieta-Moreno, J.I., Trabada, D.G., Mendieta, J., Ortega, J. Proton Transfer in Guanine-Cytosine Base Pairs in B-DNA. J. Chem. Theory Comput. 2019, 15, 12, 6984-6991". In this Comment it was outlined thoughts according the possibility for the Watson-Crick G.C DNA base pair to tautomerise by the Löwdin's mechanism and so to cause spontaneous point mutations. Based on the comprehensive analysis, authors arrive to the conclusion that mechanism, which has been analyzed in work (J. Chem. Theory Comput. 2019, 15, 12, 6984-6991) is not possible.

Ke y wo rds: Spontaneous point mutations in DNA, proton transfer, Watson-Crick G.C DNA base pair, Löwdin's mechanism.

$\mathrm{D}$ espite continuous and significant efforts of both theorists and experimenters, the clarification of the nature of the spontaneous point mutations in DNA is the topic, which importance for the needs of biology, biochemistry, biophysics and personified medicine could not be overestimated. Nowadays, it remains clear only in the general outlines [1].

In the recent work [2] with the application of the novel calculation approaches and algorithms on the modeling of the extra-cellular DNA, it was confirmed the previously reached conclusion that tautomerization of the Watson-Crick G.C DNA base pair by the Löwdin's mechanism [3, 4] is not the source of the spontaneous point mutations, arising at the DNA replication $[5,6]$.

In this Comment we allow to ourselves to outline some thoughts according this topic and hope very much that they would be useful as to the authors of the work [3], so to the especially interested readers.

Choosing the appropriate model for the QM/ MM calculations, in particular - the division of the investigated system on the QM and MM regions and their combination into the complete joint system, - is not so easy task, as it could be looking like from the first glance.

As it is broadly known, the nucleotides are elementary structural units of DNA. With the overview on this fact, it would be more correctly to consider H-bonded pair of nucleotides as the QM-region instead of the pair of nucleosides, as it was considered by the authors of the work [2]. Moreover, in order to avoid the so-called edge effect, in particular for the more adequate consideration of the stacking of the neighboring base pairs and also of the sugar-phos-

(C) 2020 Brovarets' O. O., Hovorun D. M. This is an open-access article distributed under the terms of the Creative Commons Attribution License, which permits unrestricted use, distribution, and reproduction in any medium, provided the original author and source are credited. 
phate residues, it would be more logical to provide QM calculations for the three complementary pairs of nucleotides, using at this the pair of the middle nucleotides as a testing object for the mutagenic tautomerization. Authors of the work [2] intuitively extend obtained results for the $\mathrm{G} \cdot \mathrm{C}$ nucleobase pair in the concrete surrounding to the all without exception $\mathrm{G} \cdot \mathrm{C}$ DNA base pairs. At this, authors did not consider the so-called neighboring effect, that is they did not choose for investigation all possible combinations of the neighboring DNA base pairs.

It also looking like not quite optimistic the quality of the used by the authors of the work [2] model of the extra-cellular DNA - in particular, acid salt instead of the acid, absence of the proteins of replisome or at least their molecular imitation, free hydratation etc. - as realistic biomolecular system found in the cell.

Also, authors of the work [2] stayed at the half of the road, considering only the intramolecular tautomerization of the G DNA base as a possible source of the spontaneous point mutations. At this, they leave the complementary C DNA base without any explanation outside the attention and consideration. Moreover, it was not taking into account neither proton tunneling [7], nor catalytical role of the water molecule [8] in order to accelerate this process in the single-stranded DNA.

In the paper [2] it was not considered and discussed at all the kinetical characteristics of the investigated processes of the mutagenic tautomerization, which are extremely important (!) [9, 10], since replication machinery is quite passive. Moreover, authors do not compare obtained data for the energetical characteristics of the mutagenic tautomerization with the QM results of the others authors $[5,7]$. So, obtained result $\Delta \Delta \mathrm{G}=2.4 \mathrm{kcal} / \mathrm{mol}(\varepsilon=1)$ [2] significantly differs from the analogical value $\Delta \Delta \mathrm{G}=0.47 \mathrm{kcal} / \mathrm{mol}$ obtained at the MP2/aug-cc$\mathrm{pVTZ} / / \mathrm{MP} 2 / 6-311++\mathrm{G}(\mathrm{d}, \mathrm{p})$ level of theory for the isolated G.C DNA base pair [6]. In the continuum with a low dielectric constant $(\varepsilon=4) \Delta \Delta G=-0.65 \mathrm{kcal} /$ mol at standard conditions [5]. This fact is not even mentioned and commented in the work [2].

It also looking not quite convincing the ideology of the planning of the investigations [2]. Thus, from the one side, the authors agree with the fact, that DPT tautomerization by the Löwdin's mechanism $[3,4]$ of the Watson-Crick A-T DNA base pair is not the source of the spontaneous point mutations $[6,11]$, since the Gibbs free energy of the reverse barrier $\Delta \Delta \mathrm{G}<0$ [11] and so the tunneling of the pro- tons is not possible [12]. At the same time, ignoring the analogical conclusions for the Watson-Crick G. C DNA base pair [5, 6], they started to investigate in hope that it would have the different from the A.T DNA base pair behavior. Such logic, as for our opinion, it quite weak and vulnerable, since the ability of the Watson-Crick DNA base pairs for the mutagenic tautomerization are their evolutionary acquired property [1] and it should not be believed that the behavior of the evolutionary latest G.C DNA base pair [13] would be significantly different from the analogical behavior of the Watson-Crick A-T DNA base pair as a result of the accidental deviation of the evolution from the strategical aim - functional expediency [14].

And finally, the last, but not least. After the careful reading and analysis of this paper [2], the readers can doubt, whether the classical tautomeric hypothesis [15] is adequate within the framework of the Löwdin's model [3, 4] and intramolecular mutagenic tautomerization of the DNA bases [7, 16]. Fortunately, there are no reasons for such suggestions.

The point is that nowadays it was discovered and basically substantiated novel mechanisms of the mutagenic tautomerization of the right [17] and so-called incorrect [18] DNA base pairs, which are active players in the field of the spontaneous point mutagenesis [1], giving tautomeric hypothesis "the second breath", filling it with the novel physicochemical sense. So, it could be reliably stated that this great idea [15] has passed the test of time.

Conflict of interest. Authors have completed the Unified Conflicts of Interest form at http://ukrbiochemjournal.org/wp-content/uploads/2018/12/ coi_disclosure.pdf and declare no conflict of interest.

\section{ТАУТОМЕРНА ГІПОТЕЗА: БУТИ ЧИ НЕ БУТИ? КВАНТОВО- МЕХАНІЧНИЙ ВЕРДИКТ}

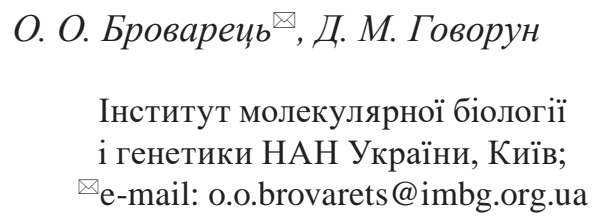

Ця стаття $є$ критичним коментарем роботи «Soler-Polo, D., Mendieta-Moreno, J.I., Trabada, D.G., Mendieta, J., Ortega, J. Proton Transfer in Guanine-Cytosine Base Pairs in B-DNA. J. Chem. Theory Comput. 2019, 15, 12, 6984-6991». У ньому 
викладено міркування щодо можливості таутомеризації Уотсон-Криківської пари основ G-C в ДНК відповідно до механізму Льовдіна, а відтак i до спричинення спонтанних точкових мутацій. На основі всебічного аналізу автори дійшли висновку, що запропонований механізм є неможливим.

К л юч о в і с лов а: спонтанні точкові мутації в ДНК, протонне перенесення, УотсонКриківська пара основ G-C в ДНК, механізм Льовдіна.

\section{References}

1. Brovarets' OO, HovorunDM. Key Microstructural Mechanisms of the 2-aminopurine Mutagenicity: Results of Extensive Quantum-Chemical Research. J Biomol Struct Dyn. 2019; 37(10): 2716-2732.

2. Soler-Polo D, Mendieta-Moreno JI, Trabada DG, Mendieta J, Ortega J. Proton Transfer in Guanine-Cytosine Base Pairs in B-DNA. J Chem Theory Comput. 2019; 15(12): 6984-6991.

3. Löwdin PO. Proton tunneling in DNA and its biological implications. Rev Mod Phys. 1963; 35(3): 724-732.

4. Löwdin PO. Quantum genetics and the aperiodic solid: some aspects on the biological problems of heredity, mutations, aging, and tumors in view of the quantum theory of the DNA molecule. Adv Quantum Chem. 1966; 2: 213-360.

5. Brovarets' OO, Hovorun DM. Why the Tautomerization of the $\mathrm{G} \cdot \mathrm{C}$ Watson-Crick Base Pair via the DPT Does Not Cause Point Mutations During DNA Replication? QM and QTAIM Comprehensive Analysis. J Biomol Struct Dyn. 2014; 32(9): 1474-1499.

6. Pérez A, Tuckerman ME, Hjalmarson HP, von Lilienfeld OA. Enol Tautomers of Watson-Crick Base Pair Models Are Metastable Because of Nuclear Quantum Effects. J Am Chem Soc. 2010; 132(33): 11510-11515.

7. Brovarets' OO, Hovorun DM. How stable are the mutagenic tautomers of DNA bases? Biopolym Cell. 2010; 26(1): 72-76.

8. Brovarets' OO, Kolomiets IM, Hovorun DM. Elementary molecular mechanisms of the spontaneous point mutations in DNA: A novel quantum-chemical insight into the classical understanding. In: Quantum Chemistry-
Molecules for Innovations (Ed. By Dr. Tomofumi Tada). InTechOpen, 2012, p. 59-102.

9. Brovarets' OO, Hovorun DM. Tautomeric Transition Between Wobble A.C DNA Base Mispair and Watson-Crick-like A. C* Mismatch: Microstructural Mechanism and Biological Significance. Phys Chem Chem Phys. 2015; 17(23): 15103-15110.

10. Brovarets' OO, Hovorun DM. How Many Tautomerization Pathways Connect WatsonCrick-like $\mathrm{G}^{*} \cdot \mathrm{T}$ DNA Base Mispair and Wobble Mismatches? J Biomol Struct Dyn. 2015; 33(11): 2297-2315.

11. Brovarets' OO, Hovorun DM. Can Tautomerization of the A.T Watson-Crick Base Pair via Double Proton Transfer Provoke Point Mutations During DNA Replication? A Comprehensive QM and QTAIM Analysis. J Biomol Struct Dyn. 2014; 32(1): 127-154.

12. Brovarets' OO, Hovorun DM. Proton Tunneling in the A.T Watson-Crick DNA Base Pair: Myth or Reality? J Biomol Struct Dyn. 2015; 33(12): 2716-2720.

13. Rich A. In: Horizons in Biochemistry. Eds. Kasha, M. and Pullman, B., Academic Press: New York: 1962, p. 103.

14. The origins of prebiological systems and of their molecular matrices. Ed. By Fox, S.W. - New York, London, 1965.

15. Watson JD, Crick FH. The Structure of DNA. Cold Spring Harb Symp Quant Biol. 1953; 18: 123-131.

16. Crick FHC, Watson JD. The complementary structure of deoxyribonucleic acid. Proc Roy Soc Lond Ser A. Math Phys Sci. 1954; 223(1152): 80-96.

17. Brovarets' OO, Hovorun DM. New structural hypostases of the $\mathrm{A} \cdot \mathrm{T}$ and $\mathrm{G} \cdot \mathrm{C}$ Watson-Crick DNA base pairs caused by their mutagenic tautomerisation in a wobble manner: a QM/ QTAIM prediction. RSC Advances. 2015; 5(121): 99594-99605.

18. Brovarets' OO, Hovorun DM. Renaissance of the Tautomeric Hypothesis of the Spontaneous Point Mutations in DNA: New Ideas and Computational Approaches. Mitochondrial DNA - New Insights / Ed. by Herve Seligmann, London, United Kingdom: IntechOpen, 2018. 